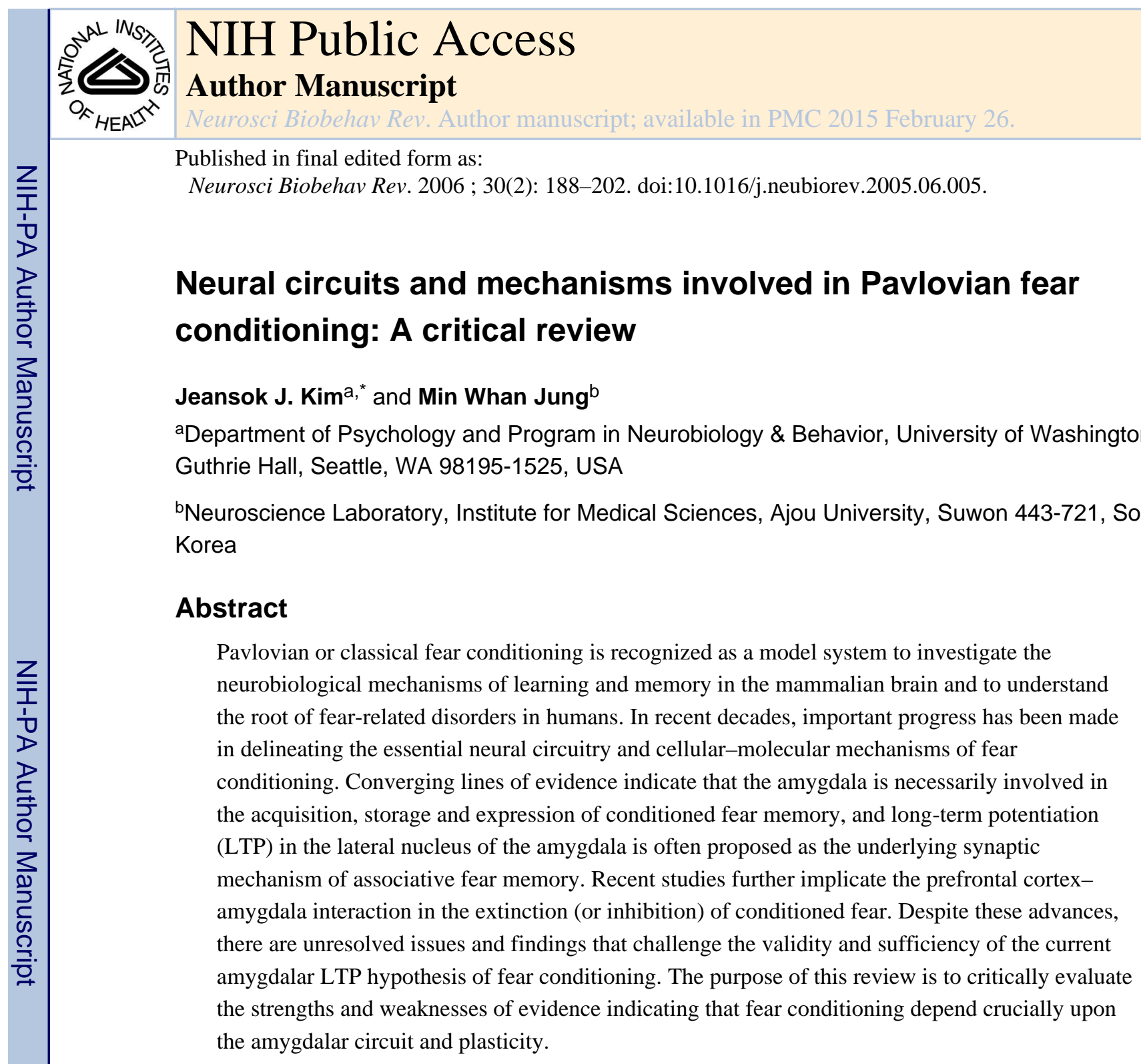

\title{
Keywords
}

Fear conditioning; Amygdala; Prefrontal cortex; LTP; NMDA

Fear is considered a defensive mechanism that evolved because of its evolutionary success in protecting animals from danger. While fear to certain kinds of stimuli is innately hardwired (e.g. a loud noise evoking fear in newborn infants, a cat inducing fear in naïve laboratory-reared rats), fear can also be acquired rapidly and lastingly to different stimuli allowing animals to respond adaptively to new or changing environmental situations. In the laboratory setting, Pavlovian or classical fear conditioning has become the par excellence task for studying the anatomical, cellular and molecular bases of fear memory formation in the brain.

(C) 2005 Elsevier Ltd. All rights reserved.

*Corresponding author. Tel.: +1 206616 2685; fax: +1 206685 3157. jeansokk@u.washington.edu (J.J. Kim). 


\section{What is fear conditioning?}

Fear conditioning occurs when initially innocuous conditioned stimulus (CS) is contingently paired with an aversive unconditioned stimulus (US) that reflexively activates unconditioned fear responses (URs) (Rescorla, 1968; Watson and Rayner, 1920). Through CS-US association formation, the CS comes to elicit various conditioned responses (CRs) that share similar characteristics to innate fear responses. Perhaps the best-known example of fear conditioning is the Little Albert experiment by Watson and Rayner in 1920 (Watson and Rayner, 1920). Little Albert was an 11-month-old infant who initially exhibited curiosity (and no fear) to a white rat by touching and playing with it. As Albert's hand touched the rat, the experimenters banged a steel bar with a hammer behind his head (US), causing him to startle, fall forward and cry (UR). Afterwards, when the rat (CS) was placed near Little Albert's hand, he withdrew his hand and began to cry (CR). This exhibition of fear towards the rat was alleged to have generalized to other white, furry animals and objects (e.g. rabbits, dogs, fur muffs).

Modern investigations of fear conditioning typically employ small mammals (such as rats, mice and rabbits) as experimental subjects and use a tone (or a light or an experimental chamber) as a CS and a mild electric shock (e.g. a footshock) as a US. Under these circumstances a small number of CS-US pairings produce robust fear learning as evidenced by a variety of fear responses exhibited upon subsequent presentations of the CS. It is important to note here that while most neurobiological studies employ simple temporal pairings (or contiguity) of CS and US to produce fear conditioning, it is the informational relationship (or contingency) between the CS and US that is the essential determinant of classical conditioning (Kamin, 1968; Rescorla, 1968; Wagner et al., 1968). In rats, typical fear CR indices include freezing (or movement arrest) (Blanchard and Blanchard, 1969, 1972; Bolles, 1970; Fanselow, 1984; LeDoux et al., 1986), enhancement of musculature reflexes (e.g. potentiated startle) (Brown et al., 1951; Davis, 1997; Leaton and Borszcz, 1985), analgesia (or decreased pain sensitivity) (Fanselow, 1986; Helmstetter, 1992), $22 \mathrm{kHz}$ ultrasonic distress vocalization (USV) (Blanchard et al., 1991; Lee et al., 2001b; Lee and Kim, 2004), and alterations in autonomic nervous system activities (e.g. increased heart rate, blood pressure, respiration rate) (Iwata et al., 1986; Kapp et al., 1979; Stiedl and Spiess, 1997). Because fear conditioning occurs very rapidly (capable with a single CS-US pairing) and with lasting effect, this task has become a popular behavioral tool for studying the cellular-molecular substrates of learning and memory (Davis, 1997; Lavond et al., 1993; LeDoux, 2000; Maren et al., 1996b).

Fear can also be quickly acquired through instrumental or operant conditioning in which the presentation of an aversive stimulus is conditional upon the behavior of the animal. A widely employed procedure with rodents is the passive (or inhibitory) avoidance task (Grossman et al., 1975; McEchron et al., 2000; Nader et al., 2000; Nagel and Kimble, 1976), in which the animal's response (e.g. entering a dark compartment of a box when placed in an adjacent lighted compartment, or stepping down from a platform onto a grid floor) is followed by a footshock. As a function of this response-stimulus pairing, the animal learns to avoid making the response that was followed by the aversive experience. While procedurally different, it is presumed that fear memories acquired via classical conditioning 
(i.e. conditioned fear) and instrumental conditioning (i.e. inhibitory avoidance) ultimately share a common neural substrate. However, as will be discussed later, these two lines of studies have often produced contradictory results.

\section{Amygdala as the locus of fear conditioning}

A large body of evidence from lesion, pharmacological and neurophysiological studies point to the amygdala (corpus amygdaloideum) —an almond-shaped group of nuclei buried deep within the temporal lobe-as the key neural system subserving fear conditioning (Davis, 1997; Fendt and Fanselow, 1999; Lavond et al., 1993; LeDoux, 1996). As one of the principal structures of the limbic system (Isaacson, 1974), the amygdala has long been implicated as a crucial emotive brain center in monkey studies (Kluver and Bucy, 1937; MacLean and Delgado, 1953; Weiskrantz, 1956). Anatomically, the amygdala receives sensory inputs from diverse areas of the brain (e.g. thalamus, neocortex, olfactory cortex, hippocampus) and sends projections to various autonomic and somatomotor structures thought to mediate specific fear responses (e.g. bed nucleus of stria terminalis for activating stress hormones, periaqueductal gray matter for freezing, lateral hypothalamus for sympathetic activation) (LeDoux, 1996). It is generally accepted that sensory information enters the amygdala through its basal and lateral nuclei (BLA) (Aggleton, 2000; LeDoux, 1996; but see Pare et al., 2004 for an alternative view) where CS-US association (or fear memory trace) formation is believed to take place (Fig. 1). These nuclei are interconnected with the central nucleus $(\mathrm{CeA})$, which is thought to be the main amygdaloid output structure sending projections to various autonomic and somatomotor centers involved in mediating specific fear responses. In the subsequent section, we will critically examine various types of experimental evidence indicating that the amygdala is the locus of fear learning and memory storage.

\subsection{Evidence from lesion-inactivation studies}

Permanent lesions of the amygdala effectively attenuate or abolish a variety of fear CRs in several mammalian species. In rats, amygdalar lesions impair both acquisition and expression of conditioned increase in blood pressure (Iwata et al., 1986), potentiated startle (Hitchcock and Davis, 1986; Hitchcock and Davis, 1987), analgesia (Helmstetter, 1992), USV (Goldstein et al., 1996; Lee and Kim, 2004), and freezing (Blanchard and Blanchard, 1972; Cousens and Otto, 1998; Iwata et al., 1986; Kim et al., 1993). Similarly, reversible inactivation of neurons in BLA prior to fear conditioning, via infusing the $\gamma$-aminobutyric acid $\left(\mathrm{GABA}_{\mathrm{A}}\right)$ receptor agonist muscimol, blocks the acquisition of conditioned fear, while amygdalar muscimol infusions (prior to retention testing) in previously fear conditioned rats impair the expression of conditioned fear (Helmstetter and Bellgowan, 1994; Muller et al., 1997; Wilensky et al., 1999). In rabbits, amygdalar lesions have been shown to impede conditioned bradycardia (deceleration in heart rate) (Gentile et al., 1986; Kapp et al., 1979), whereas in cats, reversible cryogenic (cooling) inactivation of the CeA reduces conditioned blood pressure and respiratory responses (Zhang et al., 1986).

In addition to affecting fear CRs, amygdalar lesions also interfere with the expression of fear URs. For instance, amygdalectomized rats are unable to display normal defensive freezing behavior in the presence of a cat predator (Blanchard and Blanchard, 1972). Amygdalar 
lesions also reduce reactivity to the footshock US and block shock-induced sensitization of startle (Hitchcock et al., 1989; Kim and Davis, 1993; but see Cahill and McGaugh, 1990 and Sananes and Davis, 1992). The fact that amygdalar lesions interfere with both fear CRs and URs suggests that the amygdala receives information about both CS and US, which satisfies an essential criterion for locus of associative learning.

Lesions restricted to particular structures afferent to the amygdala can impede fear conditioning to specific CS modalities. For example, lesions to the medial division of medial geniculate nucleus (mMGN) of the thalamus, which relays auditory information to the amygdala (LeDoux et al., 1990), block the formation of tone-footshock, but not lightfootshock, association (Campeau and Davis, 1995; LeDoux et al., 1986). Similarly, in rabbits, Schneiderman and colleagues (Jarrell et al., 1986) made partial lesions in the MGN (limited to the medial border) and found that the lesioned animals did not demonstrate differential bradycardia CRs to CS+ (reinforced) and CS- (unreinforced) tones, even though the magnitude of the bradycardia response was not affected. Amygdalar lesions, by contrast, abolished the retention of differential fear conditioning of bradycardia in rabbits (Gentile et al., 1986). These results suggest that the MGN relays auditory CS information to the amygdala, where fear conditioning is believed to take place. LeDoux and colleagues (Romanski and LeDoux, 1992) have elegantly shown that the MGN sends auditory information to the amygdala both directly (via the thalamo-amygdala pathway) and indirectly (via the thalamo-cortico-amygdala pathway), with each pathway fully capable of supporting auditory fear conditioning. On the efferent side, the amygdala sends projections to particular hypothalamic and brainstem areas thought to mediate specific fear responses (Francis et al., 1981; Hitchcock et al., 1989; Iwata et al., 1986; Kim et al., 1993). For instance, lesions to the lateral hypothalamus impair conditioned blood pressure response (but not conditioned freezing), whereas lesions to the ventrolateral portion of the periaqueductal gray (PAG) matter abolish conditioned freezing response (but not conditioned blood pressure) (LeDoux et al., 1988). Lesions to the ventrolateral PAG also do not affect the expression of the conditioned bradycardia response in rabbits (Wilson and Kapp, 1994).

These examples of double dissociations of CSs and CRs, as a result of restricted damages to afferent and efferent structures to the amygdala, are consistent with the view that the amygdala is the critical site of fear conditioning. Interestingly, recent lesion studies suggest that different amygdalar nuclei (e.g. the central nucleus vs. the basal nucleus of the amygdala) mediate independent fear learning systems (e.g. the CeA controls conditioned fear responses, whereas the BLA controls instrumental fear responses) (Amorapanth et al., 2000; Killcross et al., 1997; Nader and LeDoux, 1997). The possible existence of multiple fear learning systems is perhaps not unexpected given the evolutionary importance of fear in survival.

\subsection{Evidence from stimulation and recording studies}

Electrical and chemical stimulation of specific regions in the amygdala have been shown to elicit conditioned fear-like responses. In rats, amygdala stimulation produces freezing (Weingarten and White, 1978), cardiovascular changes (Iwata et al., 1987), and enhanced 
startle responses (Rosen and Davis, 1988). In rabbits, CeA stimulation induces bradycardia, pupillodilation, arrest of ongoing behavior (such as mouth and tongue movements), and enhanced amplitude of the nictitating membrane reflex (Applegate et al., 1983; Whalen and Kapp, 1991). Stimulation of the lateral hypothalamus, an efferent target of the amygdala, generates cardiovascular responses in anesthetized rabbits (Gellman et al., 1981). These findings suggest that the amygdala can activate an ensemble of fear responses and also inhibit competing responses that are incompatible with fear responses. In some cases, however, stimulation of the amygdala can interfere with aversive learning. For example, immediate post-training stimulation of the amygdala produces amnesia that impairs the formation of fear memory (Gold et al., 1975; McDonough and Kesner, 1971). Presumably, post-training amygdalar stimulation interferes with fear conditioning-induced neuronal activities involved in the formation of fear memory.

Unit recording studies reveal that neurons in the CeA respond to both CS and US (Pascoe and Kapp, 1985) and undergo learning-related changes during fear conditioning (Applegate et al., 1983). Using a differential conditioning paradigm, Pascoe and Kapp (1985) reported that CeA neurons exhibited selective increases in single unit activity to a tone (CS+) that signaled the US, but not to a different tone (CS-) that did not signal the US. The conditioned bradycardia response paralleled the neuronal response; it was observed preferentially during the reinforced tone presentation. In addition, the magnitude of the amygdalar unit activity correlated with the magnitude of the conditioned bradycardia response. It appears that during fear conditioning some form(s) of neurophysiological changes strengthen(s) the CS-amygdala pathway such that the CS now becomes capable of eliciting conditioned fear responses.

\subsection{Evidence from pharmacological studies}

Immediate post-training drug manipulations in the amygdala can impair or enhance aversive memories. In 1978, Gallagher and Kapp (1978) first demonstrated that infusions of the opioid receptor antagonist naloxone directly into the amygdala enhance fear conditioning. In contrast, infusions of the opioid agonist levorphanol reduced fear conditioning (Gallagher et al., 1981). Subsequent studies indicate that the memory-enhancing effect of opiate antagonists is induced partly by blocking the endogenously released opioids from inhibiting the release of norepinepherine in the amygdala (McGaugh, 1989). For instance, amygdalar infusions of the noradrenergic receptor antagonist propanolol impair the retention of an inhibitory avoidance memory (Gallagher et al., 1981) and block the memory-enhancing effect of naloxone (McGaugh et al., 1988). In contrast to propanolol, post-training intraamygdalar infusions of norepinepherine enhance the retention of inhibitory avoidance memory (Liang et al., 1986). Based on results from a wide array of pharmacological studies, McGaugh and colleagues (McGaugh, 1989, 2000; McGaugh and Cahill, 1997; McGaugh et al., 1996) proposed that interactions of opioid, GABA, noradrenergic, and cholinergic neurochemical systems in the amygdala modulate aversive learning. Recently, pre-training intra-amygdalar infusions of the dopamine (D2) receptor antagonist eticlopride have been shown to markedly attenuate conditioned freezing, indicating that amygdaloid dopamine transmission also contributes to the formation of fear memories (Guarraci et al., 2000; Nader and LeDoux, 1999). Dopamine has also been shown to gate LTP induction in lateral 
amygdala by suppressing thalamo-amygdalo feedforward inhibition (Bissierre et al., 2003). Finally, drugs (such as diazepam) that decrease fear or anxiety in humans, when infused directly into the amygdala, have been shown to attenuate fear conditioning in rats (Helmstetter, 1993).

Several studies suggest that the $N$-methyl-D-aspartate (NMDA) subtype of the glutamate receptor in the amygdala might be involved in the synaptic plasticity process (i.e. LTP) underlying fear conditioning. Because NMDA receptors have been demonstrated to be critical for the induction (but not expression) of LTP in the hippocampus (e.g. the CA1 area), a similar type of synaptic plasticity in the amygdala has been proposed as a possible cellular mechanism subserving fear conditioning. Consistent with this notion, pre-training intra-amygdalar administrations of DL-2-amino-5-phosphonovaleric acid (APV or AP5)-a competitive NMDA receptor antagonist—have been shown to effectively block the acquisition of conditioned fear, as measured by fear-potentiated startle response (Miserendino et al., 1990) and freezing (Fanselow and Kim, 1994). Other studies, however, that APV infusions into the amygdala also significantly impair the expression of conditioned fear (in previously fear-conditioned rats), as measured by a variety of fear responses including freezing, USV, analgesia, as well as potentiated startle (Fendt, 2001; Lee and Kim, 1998; Lee et al., 2001b; Maren et al., 1996b). It appears then NMDA receptors are necessary for normal synaptic transmission in the amygdala, and therefore, overall functioning of the amygdala (Bauer et al., 2002). In contrast to reliable pre-training drug effects, immediate post-training administration of APV has produced equivocal results on fear conditioning (Kim and McGaugh, 1992; Kim et al., 1991).

It is important to note that results from immediate post-training drug infusion studies employing instrumental fear conditioning are generally interpreted in the framework that the amygdala is critically involved in modulating consolidation (rather than formation) of fear memory, which is hypothesized to transpire outside the amygdala (Cahill et al., 1999; McGaugh, 2000). In contrast, results from pre-training drug studies using classical fear conditioning are usually taken to support the view that the amygdala is critical for acquisition and storage of fear memory (Davis, 1997; Fendt and Fanselow, 1999; LeDoux, 2000). In both instrumental and classical fear conditioning tasks, pre-testing drug manipulations evaluate drug effects on the performance or expression of fear memory. For a drug effect to be unequivocally interpreted as impairing acquisition or consolidation of conditioned fear memory, the drug should interfere with fear conditioning only when administered either pre-training or immediate post-training, but not when administered pretesting nor should there be state-dependent effects associated with the drug. Interestingly, immediate post-training drug effects have been demonstrated reliably in instrumental fear conditioning tasks but not in classical fear conditioning tasks, suggesting that these two procedurally different fear learning tasks do not share an entirely common learning and memory mechanisms (see Lee et al., 2001a for discussion).

Consistent with the notion of the amygdala as the critical locus of fear memory storage, the acquisition of fear conditioning in rats appears to require RNA and protein synthesis in the amygdala. Pre-training intra-BLA infusions of the RNA synthesis inhibitor actinomycin-D significantly attenuate fear conditioning (to both tone and context CSs) and lower the level 
of RNA synthesis in the amygdala (Bailey et al., 1999). Similarly, immediate post-training infusions of anisomycin (a protein synthesis inhibitor) and Rp-cAMPS (an inhibitor of protein kinase A) into the lateral amygdala (LA) impair fear conditioning (Schafe and LeDoux, 2000). Once fear conditioning has been established or consolidated, intraamygdalar infusions of actinomycin-D, anisomycin and Rp-cAMPS do not affect the expression of conditioned fear (Bailey et al., 1999; Schafe and LeDoux, 2000). The fact that RNA and protein synthesis inhibitors selectively impair acquisition but not expression of conditioned fear suggests that synaptic transmission functions in the amygdala are not significantly compromised by the drugs. Regardless, these findings should be considered cautiously since it is unknown whether the drug effects are due to interfering with RNA and protein synthesis in neurons or in non-neuronal cells. For example, it is possible that inhibitions of RNA and protein synthesis in non-neuronal (e.g. glial) cells alter normal functioning of neurons (e.g. via altering glutamate neurotransmitter reuptake, glucose transport, etc.). Interestingly, previously consolidated fear memories, when reactivated during retrieval (i.e. during a brief conditioned tone test), appear to return to a labile state that again requires protein synthesis in the amygdala for reconsolidation (Nader et al., 2000).

\subsection{Evidence from synaptic plasticity studies}

LTP, which is frequently suggested as a candidate synaptic mnemonic mechanism in the hippocampus (Collingridge et al., 1983; Morris et al., 1990; Teyler and DiScenna, 1987), has also been demonstrated in the amygdala, e.g. the external capsule-lateral nucleus of the amygdala (LA) pathway in vitro (Chapman and Bellavance, 1992; Chapman et al., 1990), the internal capsule-LA pathway in vitro (Huang and Kandel, 1998), the auditory thalamusLA pathway in vivo (Clugnet and LeDoux, 1990), and the subiculum-BLA pathway in vivo (Maren and Fanselow, 1995). The auditory inputs from the MGN to the LA-a pathway involved in tone fear conditioning (LeDoux, 2000)—demonstrate an enhancement in auditory-evoked potentials (or LTP-like changes) after tone fear conditioning (Rogan and LeDoux, 1995; Rogan et al., 1997). Similarly, amygdalar slices prepared from fearconditioned rats exhibit enhanced synaptic transmission in the MGN-amygdala pathway (Collins and Pare, 2000; McKernan and Shinnick-Gallagher, 1997; Quirk et al., 1997; Quirk et al., 1995; Repa et al., 2001; Rosenkranz and Grace, 2001). Thus, it has been postulated that Hebbian form of associative LTP in the amygdala is involved in fear conditioning (Blair et al., 2001; Clugnet and LeDoux, 1990; Davis, 1997; Fanselow and Kim, 1994; LeDoux, 2000; Maren and Fanselow, 1995; Miserendino et al., 1990). Specifically, fear conditioning is thought to occur when initially weak CS path to the amygdala become strengthened (via LTP) by being temporally paired with strong US path to the amygdala. However, associative LTP with temporal parameters congruent to fear conditioning has yet to be demonstrated in the amygdala by stimulating CS and US input pathways to the amygdala.

As first demonstrated in the hippocampus (e.g. the Schaffer collateral/commissural-CA1 pathway), NMDA receptors have been implicated in the development of LTP in the amygdala. But unlike the CA1 LTP, where NMDA receptor antagonists have been shown to block the induction of LTP without impeding the normal synaptic transmission or affecting the expression of already established LTP, the precise role of the NMDA receptors in amygdalar LTP is unclear. In an earlier study, the APV concentration required to block the 
induction of LTP in the amygdala also markedly impaired normal synaptic transmission (Chapman and Bellavance, 1992). Another study also failed to block amygdalar LTP with APV, but short-term potentiation was impaired by APV (Li et al., 1998). Correspondingly, a single-unit recording study indicates that the normal auditory-evoked response in the amygdala is attenuated by APV, suggesting that the NMDA receptors are involved in the normal synaptic transmission of the thalamo-LA pathway that mediates auditory fear conditioning (Li et al., 1998). Thus, the receptor mechanisms responsible for the induction of amygdalar LTP remain uncertain and may depend on the particular synapses and input pathway (Chapman et al., 1990; LeDoux, 2000; Weisskopf and LeDoux, 1999).

In all amygdalar LTP studies performed up-to-date, single test pulse stimulation has been used to evaluate the effect of APV on 'normal' synaptic transmission. However, this is an artificial stimulation condition for assessing synaptic transmission. Under different stimulation patterns (for example, during a burst stimulation condition), the NMDAmediated component of synaptic transmission might be large (due to depolarization relieving a voltage-dependent $\mathrm{Mg}^{2+}$ blockade of the NMDA receptor channel), in which case APV will significantly interfere with synaptic transmission. Presumably, the pattern of afferent input activities to the amygdala representing the CS information (such as tone) will be considerably different from those generated with a single test pulse stimulation used in LTP studies.

\subsection{Evidence from human studies}

Recent findings from human neuropsychological and brain imaging studies also support the view that the amygdala is critically involved in fear conditioning. Patients with damage to the amygdala display a selective impairment in the recognition of facial expressions of fear (Adolphs et al., 1994) and also exhibit deficits in fear conditioning (LaBar et al., 1995) in contrast to normal subjects. Amygdalar-damaged patients are also impaired in recalling emotionally influenced memory (Cahill et al., 1995). Correspondingly, imaging studies show that there is a significantly increased blood flow to the amygdala (as measured by fMRI) when normal subjects are presented with pictures of fearful faces (Morris et al., 1996) or are undergoing fear conditioning (Knight et al., 1999; LaBar et al., 1998). Functional activation of the amygdala has also been observed (via PET) during free recall of emotional information (Cahill et al., 1996). These sources of evidence are consistent with the view that the amygdala is involved in fear conditioning and/or processing emotional information.

A caveat to consider in interpreting human fear conditioning studies is the 'realness' of fear involved in the task. Prior to fear conditioning experiments, for example, researchers are required to provide certain details about the behavioral procedure to human subjects, and presumably the subjects know a priori that their life will not be at risk during the experiment. Also, the perceived and physical severity of the US will be considerably less in humans compared to animals. Under these conditions, it is possible that different engagements of neural structures may be obtained in human studies from those of animal studies. 


\section{Brain areas other than the amygdala}

Most of the evidence presented to this point suggests that the amygdala is the site of fear conditioning. It is unclear, however, whether the amygdala is the permanent storage site for long-term fear memory. The site of learning is not necessarily the site of memory storage. For example, fear retention is abolished if the amygdala is lesioned (electrolytically) or reversibly inactivated (via infusions of a local anesthetic agent lidocaine) shortly (1 day) but not long (21 days) after inhibitory avoidance training (Liang et al., 1982), suggesting that long-term fear memory is not stored in the amygdala. In contrast to inhibitory avoidance, amygdalar lesions made either shortly ( 1 day) or long ( 7 or 28 days) after training effectively abolish conditioned freezing response (Maren et al., 1996a). Surprisingly, extensive overtraining mitigates amygdalar-lesion effects on fear conditioning (Kim and Davis, 1993), as well as inhibitory avoidance (Parent et al., 1992). Although these results indicate that the amygdala is a component of multiple fear systems in the brain, the fact that amygdala lesions (and inactivation) effectively abolish initial fear conditioning suggests that the amygdala may be the default fear learning structure.

\subsection{Insular cortex}

The insular cortex that receives and relays sensory (e.g. visual) information to the amygdala (Turner and Zimmer, 1984) may have some role in the storage of fear memory. Lesions to the most caudal aspect of the insular cortex impair retention of fear-potentiated startle with a visual CS (Rosen et al., 1992). Similarly, reversible inactivation of the insular cortex by a $\mathrm{Na}^{+}$-channel blocker tetrodotoxin impairs retention of inhibitory avoidance memory (Bermudez-Rattoni et al., 1991).

\subsection{Hippocampus}

The hippocampus seems to be involved in certain types of conditioned fear memory. In rats, conditioned fear to a diffuse contextual cue, but not to a discrete tone cue, is abolished when the hippocampus is lesioned shortly (1 day) after conditioning (Anagnostars et al., 1999; Kim and Fanselow, 1992; Maren et al., 1997). However, animals retain a considerable amount of contextual fear when a long delay ( 28 days) is imposed between the time of conditioning and the time of hippocampectomy. Thus, it appears that the hippocampus is transiently involved in storing contextual fear memory. Similarly, pre-training hippocampal lesions selectively block the acquisition of context fear memory, but not tone fear memory (Phillips and LeDoux, 1992). Additionally, lesions to the nucleus accumbens (a target of hippocampal efferents) obstruct contextual fear conditioning without affecting auditory fear conditioning (Riedel et al., 1997). Analogous to trace eyeblink conditioning in rabbits (Kim et al., 1995; Moyer et al., 1990; Solomon et al., 1986), hippocampal lesions have also been shown to impair trace (but not delay) fear conditioning to an auditory CS in rats (as measured by freezing) (McEchron et al., 1998) and rabbits (as measured by heart rate) (McEchron et al., 2000). The notion that the hippocampus is involved in contextual and trace fear conditioning are also supported by various knockout/transgenic mice studies. Specifically, mutant mice with deficient LTP in the hippocampus also exhibit deficits in contextual (but not tone) fear conditioning and trace (but not delay) fear conditioning (Abeliovich et al., 1993; Bourtchuladze et al., 1994; Huerta et al., 2000). A recent study by 
Thompson and colleagues (Liu et al., 2004a) provides strong additional evidence for the correlation between hippocampal LTP and contextual fear. They have eloquently demonstrated that both contextual fear memory and hippocampal LTP deficits observed in brain-derived neurotropic factor (BDNF) knockout mice can be rescued by infusing BDNF proteins into the hippocampus. It should be noted that different hippocampal subregions have been implicated in different aspects of behavior, i.e. the dorsal subregion for spatialrelated behaviors and the ventral subregion for anxiety-related behaviors (see Bannerman et al., 2004 for review). Thus, it is conceivable that different hippocampal subregions process different aspects of fear conditioning.

\subsection{Perirhinal cortex}

The perirhinal cortex, which is reciprocally connected to the hippocampus (both directly and indirectly via the entorhinal cortex), may be involved in early consolidation and/or storage of hippocampus-dependent contextual memory. Neurotoxic lesions of the perirhinal cortex made 1 day, but not 28 days, after training produce marked deficits in contextual fear memory (Bucci et al., 2000).

\subsection{Cerebellum}

Finally, lesions of the cerebellar vermis in rats have been reported to abolish the conditioned autonomic response (heart rate) without affecting the unconditioned autonomic response (Supple and Leaton, 1990). The vermal lesioned rats also exhibit less freezing to a cat predator and fewer signs of fear in an open field (Supple et al., 1987). In rabbits, during fear conditioning, single unit recordings of Purkinje cells in the vermis demonstrate selective increases in activity to a tone (CS+) that signaled the US, but not to a different tone (CS-) that did not signal the US. The differential unit activities of Purkinje cells correlated with the behavioral conditioned autonomic response (Supple et al., 1993). Recent studies have shown that tetrodotoxin-induced reversible inactivation of the cerebellar cortex abolishes the retention of conditioned fear memory (Sacchetti et al., 2002), and that fear conditioning induces LTP in the parallel fibers-Purkinje cell synapses in vermal lobules V-VI (Sacchetti et al., 2004). These results indicate that the cerebellar vermis may be an important part of the fear conditioning circuit and modulates fear-related behaviors.

\section{Other critical issues}

Although much is known about the neuroanatomy and neural mechanisms underlying fear conditioning, there are several unresolved and conflicting issues in the field that warrant discussion. This section will highlight four key issues in fear conditioning. What is the essential US pathway? What is the role of NMDA receptors in amygdalar LTP? Is the amygdala the permanent storage site of fear memory? And, what is the precise intraamygdala circuit mediating fear conditioning?

\subsection{Essential US pathway in fear conditioning}

While the CS pathway (specifically the auditory projection) to the amygdala is relatively well defined, the footshock (US) pathway to the amygdala has not been adequately delineated. One study reported that combined lesions of the posterior extension of the 
intralaminar complex (PINT) and caudal insular cortex (INS) block acquisition of fearpotentiated startle, and proposed that PINT-INS projections to the amygdala constitute the essential US pathways involved in fear conditioning (Shi and Davis, 1999). However, another study (Brunzell and Kim, 2001) reported that fear conditioning (as assessed by freezing) was unaffected by either pre-training or post-training PINT-INS lesions.

Specifically, Brunzell and Kim (Brunzell and Kim, 2001) found that pre-training lesions in naïve animals do not block the acquisition of fear conditioning, and post-training lesions in previously fear conditioned animals do not lead to extinction of the CR with continued CSUS training (as would be predicted if the US information does not indeed reach the site of learning). Thus, it appears that the footshock (US) pathway is comprised of diffuse, multiple somatosensory pathways to the amygdala (Brunzell and Kim, 2001). Additional research is required to understand the specific role of the US information - as relayed via tactile vs. nociception pathways - in fear conditioning. Interestingly, a very recent study paired an auditory CS with a shock US delivered to one eyelid while the amygdala was unilaterally inactivated (via local infusions of the $\mathrm{GABA}_{\mathrm{A}}$ receptor agonist muscimol) and found that acquisition and expression of conditioned freezing entirely depended upon the amygdala contralateral (but not ipsilateral) to the shocked eyelid (Blair et al., 2004). This finding offers a powerful means to make a within-subject comparison (i.e. ipsilateral and contralateral amygdalae to the shocked eyelid) in fear conditioning studies employing neurophysiological, neurochemical and molecular biological techniques.

\subsection{Roles of NMDA receptors in amygdalar LTP}

As previously mentioned, LTP in the amygdala (demonstrated both in vivo and in vitro) is commonly suggested as a putative synaptic mechanism through which acquired fear is encoded in the amygdala. However, the receptor mechanisms responsible for the induction and expression of amygdalar LTP remain ambiguous and may depend on the particular synapses and input pathway (Chapman et al., 1990; LeDoux, 2000; Weisskopf and LeDoux, 1999), as demonstrated in the hippocampus (Grover and Teyler, 1990; Harris and Cotman, 1986; Johnston et al., 1992; Staubli and Lynch, 1990; Zalutsky and Nicoll, 1990). One study (Chapman and Bellavance, 1992) reported that APV blocks LTP induction in the BLA, but only in such high concentrations that the drug markedly impairs normal synaptic transmission. Bauer et al. (2002) also showed that APV blocks synaptic transmission and LTP (but see Huang and Kandel, 1998). Similarly, single-unit recordings indicate that normal auditory-evoked responses in the amygdala are considerably attenuated by APV, suggesting that NMDA receptors are involved in normal synaptic transmission of the auditory pathway to the LA that mediates auditory fear conditioning (Li et al., 1995). Davis and colleagues (Campeau et al., 1992; Miserendino et al., 1990) initially reported that APV (an NMDA receptor antagonist) infusions into the amygdala selectively block acquisition, but not expression, of conditioned fear, as measured by fear-potentiated startle. Their finding is remarkably similar to the effects of APV on hippocampal LTP, i.e. blocking induction without affecting expression of the Schaffer collateral/commissural-CA1 LTP (Collingridge et al., 1983). However, other studies have shown that intra-amygdalar infusions of APV dramatically interfere with the expression of multiple measures of conditioned fear, such as freezing (Lee and Kim, 2004; Maren et al., 1996b), USV, analgesia, defecation (Lee et al., 2001b), as well as fear-potentiated startle (Fendt, 2001); these results indicate that 
amygdalar NMDA receptors participate in normal synaptic transmission and thus the overall functioning of the amygdala. In contrast to APV (which blocks the entire heteromeric NMDA receptor complex, i.e. NR1-NR2A and NR1-NR2B), the NR2B subunit-selective antagonist ifenprodil in the amygdala prevents acquisition (in absence of affecting expression) of conditioned freezing (Rodrigues et al., 2001) and blocks amygdalar LTP (Bauer et al., 2002). However, the ifenprodil effects on fear conditioning and amygdala-LTP appear to contrast with NMDA receptor subtype mechanisms in the hippocampal LTP. A very recent study demonstrated that selective blockade of NMDA receptors that contain the NR2B subunit (such as by adding ifenprodil) abolishes the induction of LTD but not LTP (Liu et al., 2004b). In contrast, blockade of NR2A-containing NMDA receptors blocked LTP, but not LTD, induction. Clearly, additional studies are necessary to understand the precise receptor mechanisms of synaptic plasticity underlying fear conditioning in the amygdala.

\subsection{Permanent storage site(s) of fear memory}

If the notion that the amygdala is the locus of fear memory trace is correct, then amygdalar damage should completely and permanently block fear conditioning. However, evidence from conditioned fear and inhibitory avoidance studies provides conflicting results. Recall that Pavlovian fear conditioning and inhibitory avoidance are considered to be two procedurally different fear tasks. McGaugh and colleagues reported that although amygdalar lesions affect inhibitory avoidance learning, animals can still learn and retain fear when they are overtrained, which indicates that the amygdala is not necessary for fear learning (Parent et al., 1992). Rats that received more training prior to lesions also exhibited far greater retention of inhibitory avoidance memory. Similarly, amygdalectomized rats learned inhibitory avoidance task when trained extensively. Furthermore, retention of inhibitory avoidance memory is abolished if amygdalar lesions are made shortly after training, but not several days after training (Liang et al., 1982). In contrast to inhibitory avoidance results, the retention of conditioned fear (as measured by freezing) is completely abolished whether amygdalar lesions are made shortly or long after training (Maren et al., 1996a), which indicates that the amygdala is necessary for Pavlovian fear conditioning. However, overtraining has been shown to mitigate the amygdala lesion effects on fear conditioning (Kim and Davis, 1993), suggesting that under special circumstances fear conditioning can occur in the absence of the amygdala. Recently, it has been reported that amygdalar-lesioned rats, exhibiting impairments in conditioned freezing, are capable of demonstrating inhibitory avoidance behavior when both responses are simultaneously assessed in a Y-maze task (Vazdarjanova and McGaugh, 1998). Based on the observation that amygdalar lesions abolish both conditioned and unconditioned freezing but not avoidance behavior, Cahill, Weinberger, Roozendaal and McGaugh (Cahill et al., 1999) suggested that the amygdala is critical for the expression (or performance) of reflexive fear reactions rather than the actual learning and storage of fear memory. Instead, based on a series of inhibitory avoidance and immediate posttraining drug injection studies, McGaugh and colleagues proposed that the amygdala critically modulates the consolidation of memory occurring in extra-amygdalar structure(s) (McGaugh, 2000; McGaugh et al., 1996). It appears then that studies employing classical fear conditioning and inhibitory (passive) avoidance provide different insights into the neuronal substrate(s) underlying fear learning and memory. If a common neural 
mechanism(s) mediates both conditioned fear and inhibitory avoidance, then pharmacological manipulations influencing inhibitory avoidance learning should also affect fear conditioning in a similar manner. However, several studies employing rats and mice found that conditioned fear is not susceptible to memory modulation by various drugs when conducted in the manner described in inhibitory avoidance tasks (Lee et al., 2001a; Wilensky et al., 1999). Given the discrepancy of these findings from conditioned fear and inhibitory avoidance studies, it is clear that further studies are necessary in understanding the precise role of the amygdala in fear conditioning.

\subsection{Intra-amygdala circuit}

Finally, as previously mentioned, it is generally hypothesized that neurons in the BLA support the formation of conditioned fear memory and project to neurons in the $\mathrm{CeA}$ for the expression of conditioned fear responses. According to this serial processing-transmission view, damage to either BLA or CeA would comparably disrupt the expression of conditioned responses. In support, neurotoxic lesions of CeA neurons have been reported to abolish the expression of conditioned freezing (Goosens and Maren, 2001) and fearpotentiated startle (Campeau and Davis, 1995). Neither study, however, performed fiber staining to confirm that chemical lesions were specific to CeA neurons and did not include the fibers of passage. Neurotoxic lesions can damage fibers of passage in various areas of brain (Coffey et al., 1988; Jarrard, 1989), including CeA (Frey et al., 1997). In a very recent study (Koo et al., 2004), neurotoxic lesions of CeA neurons (confirmed by thionin dye and NeuN antibody staining) in the absence of damaging the fibers of passage (confirmed by myelin staining) were found to produce only mild deficits in conditioned fear responses. In contrast, neurotoxic lesions of BLA neurons produced robust deficits. These results do not support the currently held BLA-to-CeA serial processing-transmission view of fear conditioning, and instead suggest a parallel processing in the amygdala is involved in fear conditioning (see Koo et al., 2004 for discussion).

\section{Prefrontal cortex and extinction}

If a CS (in absence of US) is presented repeatedly to a fear-conditioned animal, the amplitude and frequency of the conditioned fear gradually decreases. This process, extinction, is believed to represent a form of new learning rather than forgetting of a previously established CS-US association, because extinction is context-specific (renewal), and an extinguished fear CR to the CS reappears with passage of time (spontaneous recovery) or after the US is presented alone without pairing with the CS (reinstatement) (see Myers and Davis, 2002 for review). It is thus likely that, following extinction, the memory for CS-US association is actively inhibited by a new memory that 'the CS no longer predicts the US'. Recently, the prefrontal cortex (PFC) has been proposed as an essential brain area for the extinction of conditioned fear. In a general sense, this proposal makes sense considering the role of the PFC in the inhibitory control of maladaptive behaviors. When a CS no longer signals a US, it would be beneficial for an animal to refrain from committing previously adaptive, but now unnecessary behavior (fear responses to the CS). In this regard, the PFC is known to project directly to a number of subcortical brain structures, including amygdala and hypothalamus, exerting inhibitory influences (Fuster, 1997). Stimulation of 
the PFC inhibits discharges of amygdaloid neurons (Quirk et al., 2003; Rosenkranz and Grace, 2001, 2002) and reduces conditioned fear responses of the animal (Milad and Quirk, 2002; Milad et al., 2004). An inverse relationship between amygdala and PFC activation was also observed in humans (Kim et al., 2003; Ochsner et al., 2002). Thus, it is quite plausible that the PFC acts as an inhibitor for the amygdala, suppressing a CR after the CS has been presented a number of times without pairing with the US. Behavioral and physiological studies supporting this possibility have been reported, but the picture is far from clear at the moment.

\subsection{Behavioral studies}

Morgan et al. (1993) were the first to report the effect of PFC lesions on fear extinction. Following pre-training lesions of the ventral medial PFC (vmPFC; infralimbic and prelimbic cortex) of rats, extinction to a CS (tone), but not to context, was delayed ('emotional perseveration'). The lesion had no effect on the initial acquisition of CS- or context-induced freezing, indicating that the vmPFC is specifically involved in the extinction of CS-induced fear response. However, Gewirtz et al. (1997), using both pre-and post-conditioning lesions, reported no difference between control and vmPFC-lesioned rats in the extinction (as well as conditioned inhibition) of fear responses (assessing both freezing and startle reflex), which contradicts the original report. Quirk et al. (2000), using a different conditioning-extinction protocol (conditioning and extinction in 1 day), reported that the vmPFC lesion did not affect acquisition or within-trial extinction of CS-induced freezing, but impaired recall of extinction on the next day. The lesioned rats showed a high level of freezing (similar to preextinction level) to the CS on day 2, indicating impairment in the retention of extinction memory. Because previous studies (Gewirtz et al., 1997; Morgan et al., 1993) employed extinction across multiple days, no extinction memory in lesioned animals on day 2 is not consistent with the report by Gewirtz et al. (1997). On the other hand, it is consistent with the study showing that extinction on day 2 , but not the acquisition of conditioned fear on day 1 , is delayed in the rats injected with 6-hydroxydopamine so that dopamine is depleted in the medial PFC (mPFC) (Morrow et al., 1999). A subsequent study (Santini et al., 2004) found that infusion of a protein synthesis inhibitor in the mPFC blocks retention of extinction memory only within a certain time window $(4 \mathrm{~h})$ following induction of extinction. Because injection of an NMDA receptor antagonist or a mitogen-activated protein kinase inhibitor into the amygdala blocks extinction of fear (Davis et al., 2003), it has been proposed that extinction memory goes through a consolidation process, initially from the amygdala afterward to the vmPFC (Santini et al., 2004). In a recent study, Morgan et al. (2003), using post-conditioning lesions of the vmPFC, found no significant effect of vmPFC lesions on extinction in rats, which is consistent with the study by Gewirtz et al. (1997). However, the lesioned animals showed reduced retention of context-induced (but not CS-induced) freezing compared with control animals. They also showed increased freezing during reacquisition (to both CS and context) and re-extinction took longer. As such, interpretation of the results is not straightforward, especially when combined with their own (Morgan et al., 1993) or other studies (Quirk et al., 2000; Santini et al., 2004). One implication of this study is that vmPFC is normally involved in utilizing inhibitory association developed during extinction. Regarding other parts of the PFC, behavioral studies found no evidence for their involvement in fear extinction. Lesions in the dorsal medial PFC enhanced fear 
reactivity, but did not alter the rate of extinction in rats (Morgan and LeDoux, 1995) or mice (Vouimba et al., 2000). Likewise, lesions in the ventrolateral PFC had no effect on fear extinction in rats (Morgan and LeDoux, 1999). These results point to the importance of the vmPFC, if any, in the extinction of conditioned fear. In contrast, a recent metabolic mapping study has shown that fear extinction is correlated with enhanced labeling in several different regions of the PFC in mice. Further, the degrees of metabolic mapping in these brain areas were well correlated with behavior (freezing) (Barrett et al., 2003), suggesting that interactions among multiple brain regions, especially among different parts of the PFC, play important roles in extinction. On the whole, behavioral studies have not generated consistent results, and some reports conflict each other.

\subsection{Physiological studies}

Neurophysiological studies also provide evidence for the involvement of PFC in extinction. Milad and Quirk (2002) have shown that neurons in rat infralimbic cortex signal extinction memory. These cells were not responsive to a CS (tone) during conditioning on the first day of extinction, but showed significant responses to the CS presentation only on day 2, suggesting that they signal memory for extinction. Moreover, infralimbic stimulation paired with the CS reduced freezing and accelerated extinction learning. These data fit nicely with their previous behavioral study (Quirk et al., 2000). Unfortunately, physiological data are not without conflicts. Previous studies have shown that mPFC neural activity correlates well with the degree of fear conditioning in rabbits (Gibbs and Powell, 1988; Powell et al., 1996) and mice (Garcia et al., 1999). In fear-conditioned rats, Baeg et al. (2001) have shown that the majority $(\sim 75 \%)$ of neurons in the prelimbic and infralimbic cortex respond significantly to a CS (tone). Neural responses gradually disappeared as extinction progressed and were reinstated by reacquisition of fear conditioning. A recent human brain imaging study also reported reduced activation of the $\mathrm{mPFC}$ during fear conditioning, which diminished as extinction progressed (Phelps et al., 2004). These studies show strong and extensive neural correlates of conditioned fear in the mPFC. This is in contrast with the study by Milad and Quirk (2002) which did not find significant neuronal responses to the CS during conditioning or extinction on day 1 in the infralimbic cortex. It is not clear why such radically different results were obtained from the same region of the brain in a similar fear conditioning task. Herry et al. (1999) have shown that synaptic responses between thalamus and $\mathrm{mPFC}$ undergo a sequence of depression and potentiation during extinction of freezing to a tone in rats. This result indicates that synaptic weights of mPFC neurons undergo alterations during within-trial extinction. This study is well in line with the results of Baeg et al. (2001) which showed unit response changes during within-trial extinction. Although synaptic weight changes do not directly map onto unit activity changes, it is unlikely that such large changes in synaptic weight are without effect on unit activity. This is especially so considering that induction of LTP or LTD in this pathway alters extinction and retention of extinction at behavioral level (Herry and Garcia, 2002). Combined, physiological studies raise the possibility that memories for both CS-US association and extinction are represented in the PFC, which is supported by a recent human brain imaging study (Gottffried and Dolan, 2004). Studies employing dopamine manipulation also suggest the role of PFC dopamine in the expression as well as extinction of conditioned fear (see Pezze and Feldon, 2004 for review). 
In sum, current understanding of the neural basis of fear extinction is much poorer compared with the acquisition of conditioned fear. The PFC has been proposed to play an important role in the extinction of learned fear and there exist behavioral and physiological data supporting this proposal. The reports are, however, not all consistent and often conflicting. Obviously, there remain more questions than answers regarding the role of the PFC in fear extinction.

\section{Concluding remarks}

In recent decades, a significant progress has been made in the delineation of the essential neural circuit and synaptic mechanism involved in fear conditioning. While the amygdalaLTP hypothesis of fear conditioning has garnered vast empirical supports, there are also incompatible data and alternative hypothesis that require consideration. Additionally, recent excitement that the prefrontal cortex-amygdala interaction may play a crucial role in the extinction of conditioned fear warrants careful examination in lieu of inconsistent results. These issues will be critical in the search of cellular-molecular substrates underlying fear conditioning and extinction. Finally, because many of the fear responses observed in fear conditioning paradigms closely resemble the characteristic behavioral and physiological symptoms of human anxiety disorders, it is generally accepted that understanding the biological mechanisms of fear acquisition and extinction will have vital clinical relevance. While perhaps true, it should be cautioned that the fact that the symptomatic manifestation of anxiety disorders is similar to the fear responses observed in fear conditioning does not necessarily mean that the underlying neuronal substrates of fear and anxiety are the same (post hoc, ergo propter hoc).

\section{Acknowledgments}

We thank Hugh T. Blair for helpful comments and EunYoung Song for assistance in manuscript preparation. This work was supported by NIH Grant R01MH64457 (J.J.K.), the KOSEF grant through the Brain Disease Research Center at Ajou University and a grant (M103KV10002-03K2201-01100) from Brain Research Center of the 21st Century Frontier Research Program funded by the Ministry of Science and Technology, the Republic of Korea (M.W.J.).

\section{References}

Abeliovich A, Paylor R, Chen C, Kim JJ, Wehner JM, Tonegawa S. PKC gamma mutant mice exhibit mild deficits in spatial and contextual learning. Cell. 1993; 75:1263-1271. [PubMed: 8269510]

Adolphs R, Tranel D, Damasio H, Damasio A. Impaired recognition of emotion in facial expressions following bilateral damage to the human amygdala. Nature. 1994; 372:669-672. [PubMed: 7990957]

Aggleton, JP. The Amygdala. 2. Oxford University Press; Oxford: 2000.

Amorapanth P, LeDoux JE, Nader K. Different lateral amygdala outputs mediate reactions and actions elicited by a fear-arousing stimulus. Nat Neurosci. 2000; 3:74-79. [PubMed: 10607398]

Anagnostars SG, Maren S, Fanselow MS. Temporally graded retrograde amnesia of contextual fear after hippocampal damage in rats: within-subjects examination. J Neurosci. 1999; 19:1106-1114. [PubMed: 9920672]

Applegate CD, Kapp BS, Underwood MD, McNall CL. Autonomic and somatomotor effects of amygdala central nucleus stimulation in awake rabbits. Physiol Behav. 1983; 31:353-360. [PubMed: 6635005] 
Baeg EH, Kim YB, Jang J, Kim HT, Mook-Jung I, Jung MW. Fast spiking and regular spiking neural correlates of fear conditioning in the medial prefrontal cortex of the rat. Cereb Cortex. 2001; 11:441-451. [PubMed: 11313296]

Bailey DJ, Kim JJ, Sun W, Thompson RF, Helmstetter FJ. Acquisition of fear conditioning in rats requires the synthesis of mRNA in the amygdala. Behav Neurosci. 1999; 113:276-282. [PubMed: 10357452]

Bannerman DM, Rawlins JNP, McHugh SB, Deacon RMJ, Yee BK, Bast T, Zhang WN, Pothuizen HHJ, Feldon J. Regional dissociations within the hippocampus-memory and anxiety. Neurosci Biobehav Rev. 2004; 28:273-283. [PubMed: 15225971]

Barrett D, Shumake J, Jones D, Gonzalez-Lima F. Metabolic mapping of mouse brain activity after extinction of a conditioned emotional response. J Neurosci. 2003; 23:5740-5749. [PubMed: 12843278]

Bauer EP, Schafe GE, LeDoux JE. NMDA receptors and L-type voltage-gated calcium channels contribute to long-term potentiation and different components of fear memory formation in the lateral amygdala. J Neurosci. 2002; 22:5239-5249. [PubMed: 12077219]

Bermudez-Rattoni F, Intronini-Collison IB, McGaugh JL. Reversible inactivation of the insular cortex by tetrodotoxin produces retrograde and anterograde amnesia for inhibitory avoidance and spatial learning. Proc Natl Acad Sci. 1991; 88:5379-5382. [PubMed: 2052615]

Bissierre S, Humeau Y, Luthi A. Dopamine gates LTP induction in lateral amygdala by suppressing feedforward inhibition. Nat Neurosci. 2003; 6:587-592. [PubMed: 12740581]

Blair HT, Schafe GE, Bauer EP, Rodrigues SM, LeDoux JE. Synaptic plasticity in the lateral amygdala: a cellular hypothesis of fear conditioning. Learn Mem. 2001; 8:229-242. [PubMed: 11584069]

Blair HT, Huynh VK, Vaz VT, Van J, Patel RR, Hiteshi AK, Lee JE, Tarpley JW. Unilateral storage of fear memories by the amygdala. J Neurosci. 2004; 25:4198-4205. [PubMed: 15843623]

Blanchard RJ, Blanchard DC. Crouching as an index of fear. J Comp Physiol Psychol. 1969; 67:370375. [PubMed: 5787388]

Blanchard DC, Blanchard RJ. Innate and conditioned reactions to threat in rats with amygdaloid lesions. J Comp Physiol Psychol. 1972; 81:281-290. [PubMed: 5084445]

Blanchard RJ, Blanchard DC, Agullana R, Weiss SM. Twenty-two kHz alarm cries to presentation of a predator, by laboratory rats living in visible burrow systems. Physiol Behav. 1991; 50:967-972. [PubMed: 1805287]

Bolles RC. Species-specific defensive reactions and avoidance learning. Psychol Rev. 1970; 71:32-48.

Bourtchuladze R, Frenguelli B, Blendy J, Cioffi D, Schutz G, Silva AJ. Deficient long term memory in mice with a targeted mutation of the cAMP-responsive element-binding protein. Cell. 1994; 79:59-68. [PubMed: 7923378]

Brown JS, Kalish HI, Farber IE. Conditioned fear as revealed by magnitude of startle response to an auditory stimulus. J Exp Psychol. 1951; 41:317-328. [PubMed: 14861383]

Brunzell DH, Kim JJ. Fear conditioning to tone but not context is attenuated by lesions of insular cortex and posterior extension of intralaminar complex. Behav Neurosci. 2001; 115:365-375. [PubMed: 11345961]

Bucci DJ, Phillips RG, Burwell RB. Contributions of postrhinal and perirhinal cortices to contextual information processing. Behav Neurosci. 2000; 114:882-894. [PubMed: 11085602]

Cahill L, McGaugh JL. Amygdaloid complex lesions differentially affect retention of tasks using appetitive and aversive reinforcement. Behav Neurosci. 1990; 104:532-543. [PubMed: 2206424]

Cahill L, Babinsky R, Markowitsch H, McGaugh JL. The amygdala and emotional memory. Nature. 1995; 377:295-296. [PubMed: 7566084]

Cahill L, Haier R, Fallon J, Alkire M, Tang C, Keator D, Wu J, McGaugh JL. Amygdala activity at encoding correlated with long-term, free recall of emotional information. Proc Natl Acad Sci. 1996; 93:8016-8021. [PubMed: 8755595]

Cahill L, Weinberger NM, Roozendaal B, McGaugh JL. Is the amygdala a locus of 'conditioned fear'? Some questions and caveats. Neuron. 1999; 23:227-228. [PubMed: 10399929]

Campeau S, Davis M. Involvement of subcortical and cortical afferents to the lateral nucleus of the amygdala in fear conditioning measured with fear-potentiated startle in rats trained concurrently 
with auditory and visual conditioned stimuli. J Neurosci. 1995; 15:2312-2327. [PubMed: 7891169]

Campeau S, Miserendino MJD, Davis M. Intra-amydaloid infusion of the $N$-methyl-D-aspartate receptor antagonist AP5 blocks acquisition but not expression of fear-potentiated startle to an auditory conditioned stimulus. Behav Neurosci. 1992; 106:569-574. [PubMed: 1352104]

Chapman PF, Bellavance LL. Induction of long-term potentiation in the basolateral amygdala does not depend on NMDA receptor activation. Synapse. 1992; 11:310-318. [PubMed: 1354397]

Chapman PF, Kairiss EW, Keenan CL, Brown TH. Long-term synaptic potentiation in the amygdla. Synapse. 1990; 6:271-278. [PubMed: 2237784]

Clugnet MC, LeDoux JE. Synaptic plasticity in fear conditioning circuits: induction of LTP in the lateral nucleus of the amygdala by stimulation of the medial geneculate body. J Neurosci. 1990; 10:2818-2824. [PubMed: 2388089]

Coffey PJ, Perry VH, Allen Y, Sinden J, Rawlins JN. Ibotenic acid induced demyelination in the central nervous system: a consequence of a local inflammatory response. Neurosci Lett. 1988; 22:178-184. [PubMed: 3340323]

Collingridge GL, Kehl SJ, McLennan H. Excitatory amino acids in synaptic transmission in the Schaffer collateral-commissural pathway of the rat hippocampus. J Physiol. 1983; 334:33-46. [PubMed: 6306230]

Collins DR, Pare D. Differential fear conditioning induces reciprocal changes in the sensory responses of lateral amygdala neurons to the CS(+) and CS(-). Learn Mem. 2000; 7:97-103. [PubMed: 10753976]

Cousens G, Otto T. Both pre- and posttraining excitotoxic lesions of the basolateral amygdala abolish the expression of olfactory and contextual fear conditioning. Behav Neurosci. 1998; 112:10921103. [PubMed: 9829787]

Davis M. Neurobiology of fear responses: the role of the amygdala. J Neuropsychiatry Clin Neurosci. 1997; 9:382-402. [PubMed: 9276841]

Davis M, Walker DL, Mayers KM. Role of the amygdala in fear extinction measured with potentiated startle. Ann NY Acad Sci. 2003; 985:218-232. [PubMed: 12724161]

Fanselow MS. What is conditioned fear? Trends Neurosci. 1984; 7:460-462.

Fanselow MS. Conditioned fear-induced opiate analgesia: a competing motivational state theory of stress-analgesia. Ann NY Acad Sci. 1986; 467:40-54. [PubMed: 3524387]

Fanselow MS, Kim JJ. Acquisition of contextual Pavlovian fear conditioning is blocked by application of an NMDA receptor antagonist D,L-2-amino-5-phosphonovaleric acid to the basolateral amygdala. Behav Neurosci. 1994; 108:210-212. [PubMed: 7910746]

Fendt M. Injections of the NMDA receptor antagonist aminophosphonopentanoic acid into the lateral nucleus of the amygdala block the expression of fear-potentiated startle and freezing. J Neurosci. 2001; 21:4111-4115. [PubMed: 11356899]

Fendt M, Fanselow MS. The neuroanatomical and neurochemical basis of conditioned fear. Neurosci Biobehav Rev. 1999; 23:743-760. [PubMed: 10392663]

Francis J, Hernandez LL, Powell DA. Lateral hypothalamic lesions: effects on Pavlovian cardiac and eyeblink conditioning in the rabbit. Brain Res Bull. 1981; 6:155-163. [PubMed: 6970611]

Frey S, Morris R, Petrides M. A neuroanatomical method to assess the integrity of fibers of passage following ibotenate-induced damage to the central nervous system. Neurosci Res. 1997; 28:285288. [PubMed: 9237278]

Fuster, JM. The Prefrontal Cortex. Lippincott-Raven; Philadelphia: 1997.

Gallagher M, Kapp BS. Manipulation of opiate activity in the amygdala alters memory processes. Life Sci. 1978; 23:1973-1978. [PubMed: 214656]

Gallagher M, Kapp BS, McNall CL, Pascoe JP. Opiate effects in the amygdala central nucleus alters rabbit heart rate conditioning. Pharmacol Biochem Behav. 1981; 14:497-505. [PubMed: 7232473]

Garcia R, Vouimba RM, Baudry M, Thompson RF. The amygdala modulates prefrontal cortex activity relative to conditioned fear. Nature. 1999; 402:294-296. [PubMed: 10580500] 
Gellman MD, Schneiderman N, Wallach JH, LeBlanc W. Cardiovascular responses elicited by hypothalamic stimulation in rabbits reveal a mediolateral organization. J Auton Nerv Syst. 1981; 4:301-317. [PubMed: 7310047]

Gentile CG, Jarrell TW, Teich A, McCabe PM, Schneiderman N. The role of amygdaloid central nucleus in the retention of differential Pavlovian conditioning of bradycardia in rabbits. Behav Brain Res. 1986; 20:263-273. [PubMed: 3741587]

Gewirtz JC, Falls WA, Davis M. Normal conditioned inhibition and extinction of freezing and fearpotentiated startle following electrolytic lesions of medical prefrontal cortex in rats. Behav Neurosci. 1997; 111:712-726. [PubMed: 9267649]

Gibbs CM, Powell DA. Neuronal correlates of classically conditioned bradycardia in the rabbit: studies of the medial prefrontal cortex. Brain Res. 1988; 442:86-96. [PubMed: 3359260]

Gold PE, Hankins L, Edwards RM, Chester J, McGaugh JL. Memory interference and facilitation with posttrial amygdala stimulation: effect on memory varies with footshock level. Brain Res. 1975; 86:509-513. [PubMed: 1116015]

Goldstein LE, Rasmusson AM, Bunney BS, Roth RH. Role of the amygdala in the coordination of behavioral, neuroendocrine, and prefrontal cortical monoamine responses to psychological stress in the rat. J Neurosci. 1996; 16:4787-4798. [PubMed: 8764665]

Goosens KA, Maren S. Contextual and auditory fear conditioning are mediated by the lateral, basal, and central amygdaloid nuclei in rats. Learn Mem. 2001; 8:148-155. [PubMed: 11390634]

Gottffried JA, Dolan RJ. Human orbitofrontal cortex mediates extinction learning while accessing conditioned representations of value. Nat Neurosci. 2004; 7:1145-1153.

Grossman SP, Grossman L, Walsh L. Functional organization of the rat amygdala with respect to avoidance behavior. J Comp Physiol Psychol. 1975; 88:829-850. [PubMed: 1150951]

Grover LM, Teyler TJ. Two components of long-term potentiation induced by different patterns of afferent activation. Nature. 1990; 347:477-479. [PubMed: 1977084]

Guarraci FA, Frohardt RJ, Falls WA, Kapp BS. The effects of intra-amygdaloid infusions of a D2 dopamine receptor antagonist on Pavlovian fear conditioning. Behav Neurosci. 2000; 114:647651. [PubMed: 10883814]

Harris EW, Cotman CW. Long-term potentiation of guinea pig mossy fiber responses is not blocked by $N$-methyl-D-aspartate antagonists. Neurosci Lett. 1986; 70:132-137. [PubMed: 3022192]

Helmstetter FJ. The amygdala is essential for the expression of conditional hypoalgesia. Behav Neurosci. 1992; 106:518-528. [PubMed: 1319714]

Helmstetter FJ. Stress-induced hypoalgesia and defensive freezing are attenuated by application of diazepam to the amygdala. Pharmacol Biochem Behav. 1993; 44:433-438. [PubMed: 8446677]

Helmstetter FJ, Bellgowan PS. Effects of muscimol applied to the basolateral amygdala on acquisition and expression of contextual fear conditioning in rats. Behav Neurosci. 1994; 108:1005-1009. [PubMed: 7826507]

Herry C, Garcia R. Prefrontal cortex long-term potentiation, but not long-term depression, is associated with the maintenance of extinction of learned fear in mice. J Neurosci. 2002; 22:577583. [PubMed: 11784805]

Herry C, Vouimba RM, Garcia R. Plasticity in the mediodorsal thalamo-prefrontal cortical transmission in behaving mice. J Neurophysiol. 1999; 82:2827-2832. [PubMed: 10561450]

Hitchcock JM, Davis M. Lesions of the amygdala, but not of the cerebellum or red nucleus, block conditioned fear as measured with the potentiated startle paradigm. Behav Neurosci. 1986; 100:11-22. [PubMed: 3954873]

Hitchcock JM, Davis M. Fear-potentiated startle using an auditory conditioned stimulus: effect of lesions of the amygdala. Physiol Behav. 1987; 39:403-408. [PubMed: 3575483]

Hitchcock JM, Sananes CB, Davis M. Sensitization of the startle reflex by footshock: blockade by lesions of the central nucleus of the amygdala or its efferent pathway to the brainstem. Behav Neurosci. 1989; 103:509-518. [PubMed: 2544201]

Huang YY, Kandel ER. Postsynaptic induction and PKA-dependent expression of LTP in the lateral amygdala. Neuron. 1998; 21:169-178. [PubMed: 9697861]

Huerta PT, Sun LD, Wilson MA, Tonegawa S. Formation of temporal memory requires NMDA receptors within CA1 pyramidal neurons. Neuron. 2000; 25:473-480. [PubMed: 10719900] 
Isaacson, RL. The Limbic System. 2. Plenum; New York: 1974.

Iwata J, LeDoux JE, Reis DJ. Destruction of intrinsic neurons in the lateral hypothalamus disrupts the classical conditioning of autonomic but not behavioral emotional responses in the rat. Brain Res. 1986; 368:161-166. [PubMed: 3955355]

Iwata J, Chida K, LeDoux JE. Cardiovascular responses elicited by stimulation of neurons in the central amygdaloid nucleus in awake but not anesthetized rats resemble conditioned emotional responses. Brain Res. 1987; 418:183-188. [PubMed: 2889508]

Jarrard LE. On the use of ibotenic acid to lesion selectively different components of the hippocampal formation. J Neurosci Methods. 1989; 29:251-259. [PubMed: 2477650]

Jarrell TW, Gentile CG, McCabe PM, Schneiderman N. The role of the medial geniculate region in differential Pavlovian conditioning of bradycardia in rabbits. Brain Res. 1986; 374:126-136. [PubMed: 3719322]

Johnston D, Williams S, Jaffe D, Gray R. NMDA-receptor independent long-term potentiation. Annu Rev Physiol. 1992; 54:489-505. [PubMed: 1314043]

Kamin, LJ. Miami Symposium on the Prediction of Behavior: Aversive Stimulation. Jones, MR., editor. University of Miami Press; Coral Gables: 1968. p. 9-33.

Kapp BS, Frysinger R, Gallagher M, Haselton J. Amygdala central nucleus lesions: effects on heart rate conditioning in the rabbit. Physiol Behav. 1979; 23:1109-1117. [PubMed: 542522]

Killcross S, Robbins TW, Everitt BJ. Different types of fear-conditioned behaviour mediated by separate nuclei within amygdala. Nature. 1997; 388:377-380. [PubMed: 9237754]

Kim M, Davis M. Lack of a temporal gradient of retrograde amnesia in rats with amygdala lesions assessed with the fear-potentiated startle paradigm. Behav Neurosci. 1993; 107:1088-1092. [PubMed: 8136062]

Kim JJ, Fanselow MS. Modality-specific retrograde amnesia of fear. Science. 1992; 256:675-677. [PubMed: 1585183]

Kim M, McGaugh JL. Effects of intra-amygdala injections of NMDA receptor antagonists on acquisition and retention of inhibitory avoidance. Brain Res. 1992; 585:35-48. [PubMed: 1387340]

Kim JJ, DeCola JP, Landeira-Fernandez J, Fanselow MS. $N$-methyl-D-aspartate receptor antagonist APV blocks acquisition but not expression of fear conditioning. Behav Neurosci. 1991; 105:126133. [PubMed: 1673846]

Kim JJ, Rison RA, Fanselow MS. Effects of amygdala, hippocampus, and periaqueductal gray lesions on short- and long-term contextual fear. Behav Neurosci. 1993; 107:1093-1098. [PubMed: 8136063]

Kim JJ, Clark RE, Thompson RF. Hippocampectomy impairs the memory of recently, but not remotely, acquired trace eyeblink conditioned responses. Behav Neurosci. 1995; 109:195-203. [PubMed: 7619310]

Kim H, Somerville LH, Johnstone T, Alexander AL, Whalen PJ. Inverse amygdala and medial prefrontal cortex responses to surprised faces. Neuroreport. 2003; 14:2317-2322. [PubMed: 14663183]

Kluver H, Bucy PC. 'Psychic blindness' and other symptoms following bilateral temporal lobectomy in rhesus monkeys. Am J Physiol. 1937; 119:352-353.

Knight DC, Smith CN, Stein EA, Helmstetter FJ. Functional MRI of human Pavlovian fear conditioning: patterns of activation as a function of learning. Neuroreport. 1999; 10:3665-3670. [PubMed: 10619663]

Koo JW, Han JS, Kim JJ. Selective neurotoxin lesions of basolateral and central nuclei of the amygdala produce differential effects on fear conditioning. J Neurosci. 2004; 24:7654-7662. [PubMed: 15342732]

LaBar KS, LeDoux JE, Spencer DD, Phelps EA. Impaired fear conditioning following unilateral temporal lobectomy in humans. J Neurosci. 1995; 15:6846-6855. [PubMed: 7472442]

LaBar KS, Gatenby C, Gore JC, LeDoux JE, Phelps EA. Amygdolo-cortical activation during conditioned fear acquisition and extinction: a mixed trial fMRI study. Neuron. 1998; 20:937-945. [PubMed: 9620698] 
Lavond DG, Kim JJ, Thompson RF. Mammalian brain substrates of aversive classical conditioning. Annu Rev Psychol. 1993; 44:317-342. [PubMed: 8434892]

Leaton RN, Borszcz GS. Potentiated startle: its relation to freezing and shock intensity in rats. J Exp Psychol: Anim Behav Proc. 1985; 2:248-259.

LeDoux, JE. The Emotional Brain. Simon and Schuster; New York: 1996.

LeDoux JE. Emotion circuits in the brain. Annu Rev Neurosci. 2000; 23:155-184. [PubMed: 10845062]

LeDoux JE, Iwata J, Pearl D, Reis DJ. Disruption of auditory but not visual learning by destruction of intrinsic neurons in the rat medial geniculate body. Brain Res. 1986; 371:395-399. [PubMed: 3697769]

LeDoux JE, Iwata J, Cicchetti P, Reis DJ. Different projections of the central amygdaloid nucleus mediate autonomic and behavioral correlates of conditioned fear. J Neurosci. 1988; 8:2517-2529. [PubMed: 2854842]

LeDoux JE, Farb C, Ruggiero DA. Topographic organization of neurons in the acoustic thalamus that project to the amygdala. J Neurosci. 1990; 10:1043-1054. [PubMed: 2158523]

Lee H, Kim JJ. Amygdalar NMDA receptors are critical for new fear learning in previously fearconditioned rats. J Neurosci. 1998; 18:8444-8454. [PubMed: 9763487]

Lee T, Kim JJ. Differential effects of cerebellar, amygdalar and hippocampal lesions on classical eyeblink conditioning in rats. J Neurosci. 2004; 24:3242-3250. [PubMed: 15056703]

Lee HJ, Berger SY, Stiedl O, Spiess J, Kim JJ. Post-training injections of catecholaminergic drugs do not modulate fear conditioning in rats and mice. Neurosci Lett. 2001a; 303:123-126. [PubMed: 11311508]

Lee HJ, Choi JS, Brown TH, Kim JJ. Amygdalar $N$-methyl-D-aspartate (NMDA) receptors are critical for the expression of multiple conditioned fear responses. J Neurosci. 2001b; 21:4116-4124. [PubMed: 11356900]

Li X, Phillips RG, LeDoux JE. NMDA and non-NMDA receptors contribute to synaptic transmission between the medial geniculate body and the lateral nucleus of the amygdala. Exp Brain Res. 1995; 105:87-100. [PubMed: 7589322]

Li H, Weiss SRB, Chuang D, Post RM, Rogawski MA. Bidirectional synaptic plasticity in the rat basolateral amygdala: characterization of an activity-dependent switch sensitive to the presynaptic metabotropic glutamate receptor antagonist 2 S-alpha-ethylglutamic acid. J Neurosci. 1998; 18:1662-1670. [PubMed: 9464991]

Liang KC, McGaugh JL, Martinez JL, Jensen RA, Vasquez BJ, Messing RB. Post-training amygdaloid lesions impair retention of an inhibitory avoidance response. Behav Brain Res. 1982; 4:237-249. [PubMed: 7059379]

Liang KC, Juler R, McGaugh JL. Modulating effects of postraining epinephrine on memory: involvement of the amygdala noradrenergic system. Brain Res. 1986; 368:125-133. [PubMed: 3955350]

Liu IYC, Lyons WE, Mamounas LA, Thompson RF. Brain-derived neurotropic factor plays a critical role in contextual fear conditioning. J Neurosci. 2004a; 24:7958-7963. [PubMed: 15356210]

Liu L, Wong TP, Pozza MF, Lingenhoehl K, Wang Y, Sheng M, Auberson YP, Wang YT. Role of NMDA receptor subtypes in governing the direction of hippocampal synaptic plasticity. Science. 2004b; 304:1021-1024. [PubMed: 15143284]

MacLean PD, Delgado JM. Electrical and chemical stimulation of frontotemporal portion of limbic system in the waking animal. Electroencephalogr Clin Neurophysiol Suppl. 1953; 5:91-100.

Maren S, Fanselow MS. Synaptic plasticity in the basolateral amygdala induced by hippocampal formation stimulation in vivo. J Neurosci. 1995; 15:7548-7564. [PubMed: 7472506]

Maren S, Aharonov G, Fanselow MS. Retrograde abolition of conditional fear after excitotoxic lesions in the basolateral amygdala of rats: absence of a temporal gradient. Behav Neurosci. 1996a; 110:708-717.

Maren S, Aharonov G, Stote DL. N-methyl-D-aspartate receptors in the basolateral amygdala are required for both acquisition and expression of conditioned fear in rats. Behav Neurosci. 1996b; 110:1365-1374. [PubMed: 8986338] 
Maren S, Aharonov G, Fanselow MS. Neurotoxic lesions of the dorsal hippocampus and Pavlovian fear conditioning in rats. Behav Brain Res. 1997; 88:261-274. [PubMed: 9404635]

McDonough JH, Kesner RP. Amnesia produced by brief electrical stimulation of amygdala or dorsal hippocampus in cats. J Comp Physiol Psychol. 1971; 77:171-178. [PubMed: 5166075]

McEchron MD, Bouwmeester H, Tseng W, Weiss C, Disterhoft JF. Hippocampectomy disrupts auditory trace fear conditioning and contextual fear conditioning in the rat. Hippocampus. 1998; 8:638-646. [PubMed: 9882021]

McEchron MD, Tseng W, Disterhoft JF. Neurotoxic lesions of the dorsal hippocampus disrupt auditory-cued trace heart rate (fear) conditioning in rabbits. Hippocampus. 2000; 10:739-751. [PubMed: 11153719]

McGaugh JL. Involvement of hormonal and neuromodulatory systems in the regulation of memory storage. Annu Rev Neurosci. 1989; 12:255-287. [PubMed: 2564756]

McGaugh JL. Memory—a century of consolidation. Science. 2000; 287:248-251. [PubMed: 10634773]

McGaugh JL, Cahill L. Interaction of neuromodulatory systems in modulating memory storage. Behav Brain Res. 1997; 83:31-38. [PubMed: 9062657]

McGaugh JL, Introini-Collison IB, Nagahara AH. Memory-enhancing effects of posttraining naloxone: involvement of beta-noradrenergic influences in the amygdaloid complex. Brain Res. 1988; 446:37-49. [PubMed: 2836028]

McGaugh JL, Cahill L, Roozendaal B. Involvement of the amygdala in memory storage: interaction with other brain systems. Proc Natl Acad Sci. 1996; 93:13508-13514. [PubMed: 8942964]

McKernan MG, Shinnick-Gallagher P. Fear conditioning induces a lasting potentiation of synaptic currents in vitro. Nature. 1997; 390:607-611. [PubMed: 9403689]

Milad MR, Quirk GJ. Neurons in medial prefrontal cortex signal memory for fear extinction. Nature. 2002; 420:70-74. [PubMed: 12422216]

Milad MR, Vidal-Gonzalez I, Quirk GJ. Electrical stimulation of medial prefrontal cortex reduces conditioned fear in a temporally specific manner. Behav Neurosci. 2004; 118:389-394. [PubMed: 15113265]

Miserendino MJD, Sananes CB, Melia KR, Davis M. Blocking of acquisition but not expression of conditioned fear-potentiated startle by NMDA antagonists in the amygdala. Nature. 1990; 345:716-718. [PubMed: 1972778]

Morgan MA, LeDoux JE. Differential contribution of dorsal and ventral medial prefrontal cortex to the acquisition and extinction of conditioned fear in rats. Behav Neurosci. 1995; 109:681-688. [PubMed: 7576212]

Morgan MA, LeDoux JE. Contribution of ventrolateral prefrontal cortex to the acquisition and extinction of conditioned fear in rats. Neurobiol Learn Mem. 1999; 72:244-251. [PubMed: 10536101]

Morgan MA, Romanski LM, LeDoux JE. Extinction of emotional learning: contribution of medial prefrontal cortex. Neurosci Lett. 1993; 63:109-113. [PubMed: 8295722]

Morgan MA, Schulkin J, LeDoux JE. Ventral medial prefrontal cortex and emotional perseveration: the memory for prior extinction training. Behav Brain Res. 2003; 146:121-130. [PubMed: 14643465]

Morris RG, Davis S, Butcher SP. Hippocampal synaptic plasticity and NMDA receptors: a role in information storage? Philos Trans R Soc Lond B Biol Sci. 1990; 329:187-204. [PubMed: 1978364]

Morris JS, Frith CD, Perrett DI, Rowland D, Young AW, Calder AJ, Dolan RJ. A differential neural response in the human amygdala to fearful and happy facial expressions. Nature. 1996; 383:812 815. [PubMed: 8893004]

Morrow BA, Elsworth JD, Rasmusson AM, Roth RH. The role of mesoprefrontal dopamine neurons in the acquisition and expression of conditioned fear in the rat. Neuroscience. 1999; 92:553-564. [PubMed: 10408604]

Moyer JR Jr, Deyo RA, Disterhoft JF. Hippocampectomy disrupts trace eye-blink conditioning in rabbits. Behav Neurosci. 1990; 104:243-252. [PubMed: 2346619] 
Muller J, Corodimas KP, Fridel Z, LeDoux JE. Functional inactivation of the lateral and basal nuclei of the amygdala by muscimol infusion prevents fear conditioning to an explicit conditioned stimulus and to contextual stimuli. Behav Neurosci. 1997; 111:683-691. [PubMed: 9267646]

Myers KM, Davis M. Behavioral and neural analysis of extinction. Neuron. 2002; 36:567-584. [PubMed: 12441048]

Nader K, LeDoux JE. Is it time to invoke multiple fear learning systems in the amygdala? Trends Cogn Sci. 1997; 7:241-246. [PubMed: 21223916]

Nader K, LeDoux JE. Inhibition of the mesoamygdala dopaminergic pathway impairs the retrieval of conditioned fear associations. Behav Neurosci. 1999; 113:891-901. [PubMed: 10571473]

Nader K, Schafe GE, LeDoux JE. Fear memories require protein synthesis in the amygdala for reconsolidation after retrieval. Nature. 2000; 406:722-726. [PubMed: 10963596]

Nagel JA, Kemble ED. Effects of amygdaloid lesions on the performance of rats in four passive avoidance tasks. Physiol Behav. 1976; 17:245-250. [PubMed: 996162]

Ochsner KN, Bunge SA, Gross JJ, Gabrieli JDE. Rethinking feelings: an fMRI study of the cognitive regulation of emotion. J Cogn Neurosci. 2002; 14:1215-1229. [PubMed: 12495527]

Pare D, Quick GJ, LeDoux JE. New vista on amygdala networks in conditioned fear. J Neurophysiol. 2004; 92:1-9. [PubMed: 15212433]

Parent MB, Tomaz C, McGaugh JL. Increased training in an aversively motivated task attenuates the memory impairing effects of posttraining NMDA-induced amygdala lesions. Behav Neurosci. 1992; 106:791-799.

Pascoe JP, Kapp BS. Electrophysiological characteristics of amygdaloid central nucleus neurons during Pavlovian fear conditioning in the rabbit. Behav Brain Res. 1985; 16:117-133. [PubMed: 4041212]

Pezze MA, Feldon J. Mesolimbic dopaminergic pathway in fear conditioning. Prog Neurobiol. 2004; 74:301-320. [PubMed: 15582224]

Phelps EA, Delgado MR, Nearing KI, LeDoux JE. Extinction learning in humans: role of the amygdala and vmPFC. Neuron. 2004; 43:897-905. [PubMed: 15363399]

Phillips RG, LeDoux JE. Differential contribution of amygdala and hippocampus to cued and contextual fear conditioning. Behav Neurosci. 1992; 106:274-285. [PubMed: 1590953]

Powell DA, Maxwell B, Penney J. Neuronal activity in the medial prefrontal cortex during Pavlovian eyeblink and nictitating membrane conditioning. J Neurosci. 1996; 16:6296-6306. [PubMed: 8815909]

Quirk GJ, Repa C, LeDoux JE. Fear conditioning enhances short-latency auditory responses of lateral amygdala neurons: parallel recordings in the freely behaving rat. Neuron. 1995; 15:1029-1039. [PubMed: 7576647]

Quirk GJ, Armony JL, LeDoux JE. Fear conditioning enhances different temporal components of toneevoked spike trains in auditory cortex and lateral amygdala. Neuron. 1997; 19:613-624. [PubMed: 9331352]

Quirk GJ, Russo GK, Barron JL, Lebron K. The role of ventromedial prefrontal cortex in the recovery of extinguished fear. J Neurosci. 2000; 20:6225-6231. [PubMed: 10934272]

Quirk GJ, Likhtik E, Pelletier JG, Pare D. Stimulation of medial prefrontal cortex decreases the responsiveness of central amygdala output neurons. J Neurosci. 2003; 23:8800-8807. [PubMed: 14507980]

Repa JC, Muller J, Apergis J, Desrochers TM, Zhou Y, LeDoux JE. Two different lateral amygdala cell populations contribute to the initiation and storage of memory. Nat Neurosci. 2001; 4:724731. [PubMed: 11426229]

Rescorla RA. Probability of shock in the presence and absence of CS in fear conditioning. J Comp Physiol Psychol. 1968; 66:1-5. [PubMed: 5672628]

Riedel G, Harrington NR, Hall G, Macphail EM. Nucleus accumbens lesions impair context, but not cue, conditioning in rats. Neuroreport. 1997; 8:2477-2481. [PubMed: 9261812]

Rodrigues SM, Schafe GE, LeDoux JE. Intra-amygdala blockade of the NR2B subunit of the NMDA receptor disrupts the acquisition but not the expression of fear conditioning. J Neurosci. 2001; 21:6889-6896. [PubMed: 11517276] 
Rogan MT, LeDoux JE. LTP is accompanied by commensurate enhancement of auditory-evoked responses in a fear conditioning circuit. Neuron. 1995; 15:127-136. [PubMed: 7619517]

Rogan MT, Staubli UV, LeDoux JE. Fear conditioning induces associative long-term potentiation in the amygdala. Nature. 1997; 390:604-607. [PubMed: 9403688]

Romanski LM, LeDoux JE. Equipotentiality of thalamo-amygdala and thlamo-cortico-amygdala circuits in auditory fear conditioning. J Neurosci. 1992; 12:4501-4509. [PubMed: 1331362]

Rosen JB, Davis M. Enhancement of acoustic startle by electrical stimulation of the amygdala. Physiol Behav. 1988; 48:343-349. [PubMed: 2255742]

Rosen JB, Hitchcock JM, Miserendino MJ, Falls WA, Campeau S, Davis M. Lesions of the perirhinal cortex but not of the frontal, medial prefrontal, visual, or insular cortex block fear-potentiated startle using a visual conditioned stimulus. J Neurosci. 1992; 12:4624-4633. [PubMed: 1464761]

Rosenkranz JA, Grace AA. Dopamine attenuates prefrontal cortical suppression of sensory inputs to the basolateral amygdala of rats. J Neurosci. 2001; 21:4090-4103. [PubMed: 11356897]

Rosenkranz JA, Grace AA. Cellular mechanisms of infralimbic and prelimbic prefrontal cortical inhibition and dopaminergic modulation of basolateral amygdala neurons in vivo. J Neurosci. 2002; 22:324-337. [PubMed: 11756516]

Sacchetti B, Baldi E, Lorenzini CA, Bucherelli C. Cerebellar role in fear-conditioning consolidation. Proc Natl Acad Sci USA. 2002; 99:8406-8411. [PubMed: 12034877]

Sacchetti B, Scelfo B, Tempia F, Strata P. Long-term synaptic changes induced in the cerebellar cortex by fear conditioning. Neuron. 2004; 42:973-982. [PubMed: 15207241]

Sananes CB, Davis M. $N$-methyl-D-aspartate lesions of the lateral and basolateral nuclei of the amygdala block fear-potentiated startle and shock sensitization of startle. Behav Neurosci. 1992; 106:72-80. [PubMed: 1554439]

Santini E, Ge H, Ren K, Pena de Ortiz S, Quirk GJ. Consolidation of fear extinction requires protein synthesis in the medial prefrontal cortex. J Neurosci. 2004; 24:5704-5710. [PubMed: 15215292]

Schafe GE, LeDoux JE. Memory consolidation of auditory Pavlovian fear conditioning requires protein synthesis and protein kinase A in the amygdala. J Neurosci. 2000; 20:RC96. [PubMed: 10974093]

Shi C, Davis M. Pain pathways involved in fear conditioning measured with fear-potentiated startle: lesion studies. J Neurosci. 1999; 19:420-430. [PubMed: 9870970]

Solomon PR, Vander Schaaf ER, Thompson RF, Weisz DJ. Hippocampus and trace conditioning of the rabbit's classically conditioned nictitating membrane response. Behav Neurosci. 1986; 100:729-744. [PubMed: 3778636]

Staubli U, Lynch G. Stable depression of potentiated synaptic responses in the hippocampus with 1-5 Hz stimulation. Brain Res. 1990; 9:113-118. [PubMed: 2350674]

Stiedl O, Spiess J. Effect of tone-dependent fear conditioning on heart rate and behavior of C57BL/6N mice. Behav Neurosci. 1997; 111:703-711. [PubMed: 9267648]

Supple WF, Leaton RN. Cerebellar vermis: essential for classically conditioned bradycardia in the rat. Brain Res. 1990; 509:17-23. [PubMed: 2306634]

Supple WF, Leaton RN, Fanselow MS. Effects of cerebellar vermal lesions on species-specific responses, neophobia, and taste-aversion learning in rats. Physiol Behav. 1987; 39:579-586. [PubMed: 3588702]

Supple WF, Sebastiani L, Kapp BS. Purkinje cell responses in the anterior cerebellar vermis during Pavlovian fear conditioning in the rabbit. Neuroreport. 1993; 4:975-978. [PubMed: 8369493]

Teyler TJ, DiScenna P. Long-term potentiation. Annu Rev Neurosci. 1987; 10:131-161. [PubMed: 3032063]

Turner BH, Zimmer J. The architecture and some of the interconnections of the rat's amygdala and lateral periallocortex. J Comp Neurol. 1984; 227:540-557. [PubMed: 6432860]

Vazdarjanova A, McGaugh JL. Basolateral amygdala is not critical for cognitive memory of contextual fear conditioning. Proc Natl Acad Sci. 1998; 95:15003-15007. [PubMed: 9844005]

Vouimba RM, Garcia R, Baudry M, Thompson RF. Potentiation of conditioned freezing following dorsomedial prefrontal cortex lesions does not interfere with fear reduction in mice. Behav Neurosci. 2000; 114:720-724. [PubMed: 10959531] 
Wagner AR, Logan FA, Haberlandt K, Price T. Stimulus selection in animal discrimination learning. J Exp Psychol. 1968; 76:171-180. [PubMed: 5636557]

Watson JB, Rayner R. Conditioned emotional reactions. J Exp Psychol. 1920; 3:1-14.

Weingarten H, White N. Exploration evoked by electrical stimulation of the amygdala in rats. Physiol Psychol. 1978; 6:229-235.

Weiskrantz L. Behavioral changes associated with ablation of the amygdaloid complex in monkeys. J Comp Physiol Psychol. 1956; 49:381-391. [PubMed: 13345917]

Weisskopf MG, LeDoux JE. Distinct populations of NMDA receptors at subcortical and cortical inputs to principal cells of the lateral amygdala. J Neurophysiol. 1999; 81:930-934. [PubMed: 10036290]

Whalen PJ, Kapp BS. Contributions of the amygdaloid central nucleus to the modulation of the nictitating membrane reflex in the rabbit. Behav Neurosci. 1991; 105:141-153. [PubMed: 2025386]

Wilensky AE, Schafe GE, LeDoux JE. Functional inactivation of the amygdala before but not after auditory fear conditioning prevents memory formation. J Neurosci. 1999; 19:RC48. [PubMed: 10594092]

Wilson A, Kapp BS. Effect of lesions of the ventrolateral periaqueductal gray on the Pavlovian conditioned heart rate response in the rabbit. Behav Neural Biol. 1994; 62:73-76. [PubMed: 7945148]

Zalutsky RA, Nicoll RA. Comparison of two forms of long-term potentiation in single hippocampal neurons. Science. 1990; 248:1619-1624. [PubMed: 2114039]

Zhang JX, Harper RM, Ni H. Cryogenic blockade of the central nucleus of the amygdala attenuates aversively conditioned blood pressure and respiratory responses. Brain Res. 1986; 386:136-145. [PubMed: 3779405] 


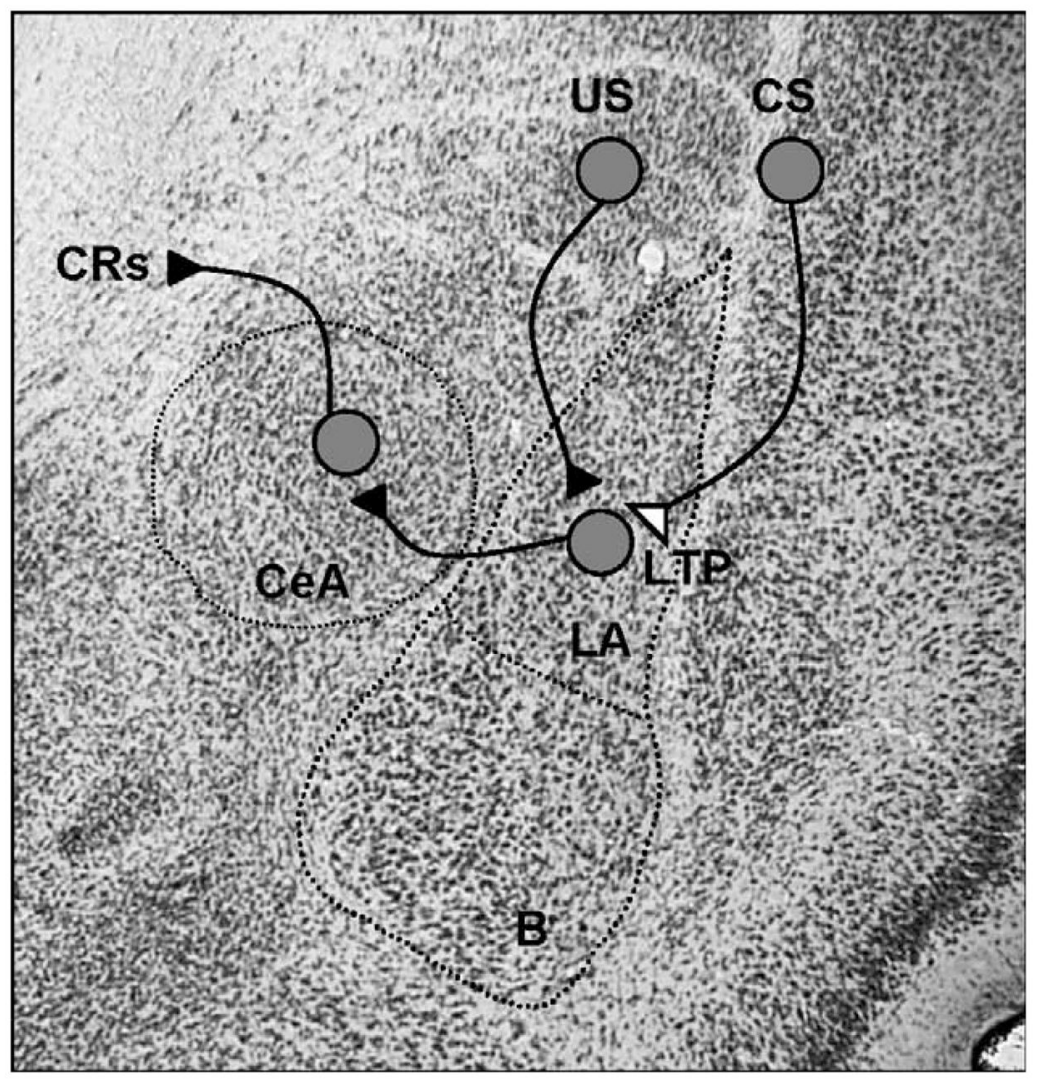

Fig. 1.

A putative amygdala-LTP model of fear conditioning. The CS and US information enters the amygdala through its basal (B) and lateral nuclei (LA) in which CS-US association formation is believed to take place via an associative LTP process. The neurons in the LA are interconnected with neurons in the CeA, which is thought to be the main amygdaloid output structure sending projections to various autonomic and somatomotor centers involved in mediating specific fear responses. 